\title{
THE 'MUSEUMS OF THE FRONTLINE' IN STEPANAKERT, OR ON THE ARMENIAN REMEMBRANCE OF THE ARMED CONFLICT WITH AZERBAIJAN
}

\author{
"Suffering does not recognize nationality" \\ - Vera Grigoryan from the Memorial Museum. The Un- \\ ion of Relatives of Missing Warriors of the NKR, 2012
}

\section{INSPIRATIONS AND METHODOLOGY}

A treatise on sociological foundations of human ecology (Socjologiczne podstawy ekologii ludzkiej) by Florian Znaniecki, then the head of the Department of Sociology and Philosophy of Culture at the University of Poznań, was published in 1938, making a significant contribution to the advancement of academic considerations on the social experience of space. Although over eighty years have passed since this publication, the tenets discussed in the treatise have rarely been employed in museology studies. Yet Znaniecki's concepts, accompanied by those of another Polish sociologist, Aleksander Wallis, who referred to Znaniecki, have provided inspiration for the analysis of the receptions of museums as a space owned by a given group.

The conceptual grid applied by Znaniecki employs the fundamental category of "spatial value" (wartość przestrzenna), which is understood not in terms of a set of physical values but rather as a component of the "non-spatial value system. This can be a religious, esthetic, technical-and-productive, economic or social system" (Znaniecki, 1938: 91). The sheer extent of these categories requires different groups of criteria to be applied for the assessment of spatial values (or: space values), of which Wallis was primarily interested in social, historical and sacral criteria (Wallis, 1983: 23). Social criteria are the outcome of treating space as the territory used and formed by a given community which associates with it a system of knowledge, ideas, values and behavioral principles, allowing them to fully identify with this territory (Znaniecki, 1938). This territory constitutes the object and at the same time an instrument of integration - "the foundation of a sense of community or strangeness, closeness or distance for different groups" (Wallis, 1983: 24). Historical criteria encompass past values, which were passed on as heritage. Sacral criteria in turn are not restricted to the representation of a specific system of religious beliefs, but pertain to all spatial phenomena, including 
secular ones, which are associated with sanctification (Wallis, 1983: 24). In practice, all these groups permeate one another, making it futile to try to draw exact borders and thus justifying the general category of 'social criteria' to be used instead (Figure 1).

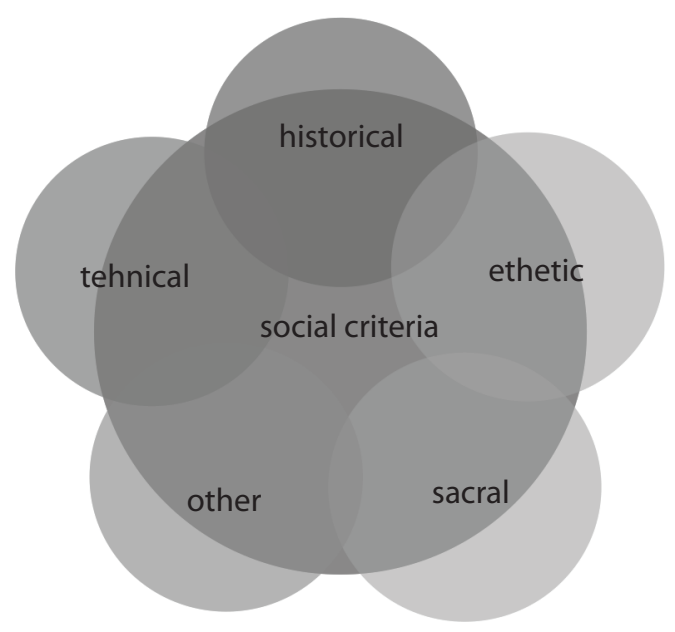

Figure 1. Social criteria of space valuation Source: Author's elaboration; cf. A. Wallis (1983), Przestrzeń jako wartość, in: id. (1990), Socjologia przestrzeni, Niezależna Oficyna Wydawnicza, Warszawa, pp. 23-24.

A decisive role in space valuation is played by culture, which is understood as the production and exchange of meanings (Hall, 1997: 2). Culture determines what is called a scopic regime, and involves the construction of what is seen and how (Rose, 2010: 21; cf. Foster, 1988: ix). The adoption of the perspective of social constructionism, or constructivism (Flick, 2004), implies that we agree that spatial values are relative and subject to change determined by the context of time and space. The fundamental epistemological premise here is that reality is the outcome of social processes. Spaces created as a consequence of these processes constitute the representation of the values of a specific group. They are treated as a non-economic 'property' used in order to perform specific collective and individual activities (Znaniecki, 1938, p. 91). Such an understanding of spatial values is exemplified by museums established by ethnic groups, or ethnoses, to commemorate victims of armed conflicts, for instance the NKR Memorial Museum of the Perished Soldiers (MMPS) and the Memorial Museum - The Union of Relatives of Missing Warriors of the NKR (MMMW). The two museums are located in Stepanakert, the capital city of the Nagorno-Karabakh Republic (NKR), alternatively named Artsakh by Armenians. This is a sovereign territory inhabited mainly by Armenians whose political institutions wield authentic power and thereby meet significant criteria of statehood. In international law, Nagorno-Karabakh is part of Azerbaijan, and the NKR is not recognized internationally. Geographically, it is a part of the South Caucasus. ${ }^{1}$

The fundamental questions to be asked are: what are the spatial values of the two museums and how are they constructed? In order to answer these questions, an auxiliary question needs to be asked: for whom? This follows from the assumption that the

${ }^{1}$ This region is also referred to as 'Transcaucasia' which is not neutral, however, as it identifies the subject speaking - Moscow. 
way of valuing space differs depending on who is looking. It is therefore necessary to identify the target group, namely the authors and recipients of the exhibition. The target group are the Armenians from Nagorno-Karabakh, an institutionalized group formally identified as being citizens of the NKR. For them, the two museums are weapons in their struggle to maintain the territorial status quo and obtain international recognition for their state, which justifies calling the two institutions 'frontline museums.' Their 'frontline' character can be interpreted in three ways:

- firstly, as the proof of remembrance of the Armenian victims of the armed conflict with Azerbaijan;

- secondly, as playing the main role in shaping Armenian national awareness;

- thirdly, metaphorically - as the borderline of the Armenian narrative about the right to Nagorno-Karabakh, beyond which the Azerbaijani alternative begins; ${ }^{2}$ this point of contact is like a meteorological 'frontline,' understood as the place where two advancing formations collide. Each of these meanings is 'local' in nature - it is an element of the social world of the Armenian population in Nagorno-Karabakh.

The construction, identification and consolidation of spatial values is a process taking place between people and the remaining actants; that is, any element that is a source of action (cf. Latour, 2019). This encompasses the interiors, the external shells and the exteriors of both museums, which affect visitors and staff. The 'interiors' are understood as the exhibition areas and exhibits as well as administrative offices, archives, etc. The 'shells' are the buildings hosting the exhibitions, while 'exteriors' are their respective locations and surroundings. In this approach, space is an actant.

During two visits to the museums in November 2017, a group of holders of spatial values formed and consolidated by the museums was represented by three members of museum staff (two from the MMPS and one from the MMMW), and over a dozen school children and their teacher who visited the exhibition (at the MMPS). My presence (in both museums) and the presence of two Russian-speaking tourists (in the MMPS) meant that the group of visitors included non-Armenians, forming a heterogeneous set distinguished on the basis of three criteria: ethnic difference from the locals, inability to speak Armenian, and the decision to take the opportunity to visit the museums while in this region. The last aggregate was temporal, which means that its existence was marked by the beginning and end of the visit to the museum.

Due to lacking the data that would be required of a representative group (such as the number of visitors, their age, place of residence, and so on), field research was conducted using techniques of observation, participatory observation and free interview; documentation was also collected in the form of photos. Quantitative methods could not be applied as there were no tickets and no system of visitor monitoring, making it impossible to collect statistics on visits to the museum. Therefore, the material col-

${ }^{2}$ The terminology in this text follows Tadeusz Świętochowski's terms 'Azeri,' applied with reference to the nation (Świętochowski, 2006: 15), and 'Azerbaijani' with reference to citizens of Azerbaijan. This decision was made due to the prevailing tendency in English literature and in Polish language practice. Nevertheless, the author is aware of reservations made by linguists, Russianspeaking scholars and Azerbaijanis themselves, who do not use word 'Azeri,' as discussed in detail by Przemysław Adamczewski, unanimously preferring the term 'Azerbaijani' (Adamczewski, 2012a: 28). 
lected was processed using qualitative methods only, including discourse analysis as the fundamental method and autoethnography and performance as auxiliary methods. Discourse analysis, rooted in the archeological and genealogical practice of Michel Foucault, made it possible to approach the museum and its surroundings as an 'archive' which is not neutral, being associated with the power inherent in accumulation and the authority inherent in the institution (Sekula, 1986: 155). The autoethnographic method involved personal testimony from the author. The situation of being distanced - being Other, but non-enemy - provided a counterpoint to the experience of the space by members of the group who own this space. This resulted in adopting the convention of writing in the first person in order to stress the subjectivity of the reception, wherever this method was applied in the research (cf. Spry, 2001: 701), as well as in the "rejection of finality and closure" (Holman Jones, 2009: 178) on a general level. Performative acts involved gestures performed during visits to both museums in order to trigger interaction on the one hand and to express one's own views on the other.

\section{EXPLORING THE MUSEUM SPACE}

Exploring the museum space is a process which begins with learning about the context within which the institutions emerged. This context includes political, historical, legal and social aspects, which had a considerable impact on the establishment, location, spatial solutions applied and the organization of these institutions.

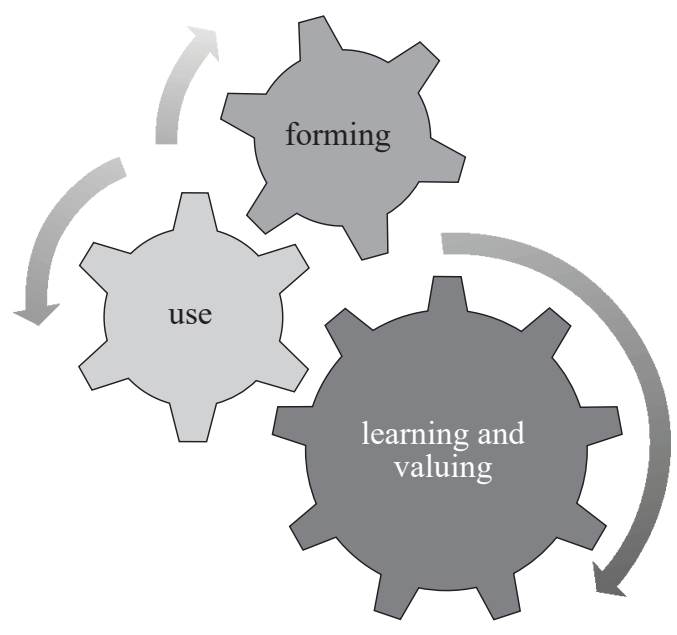

Figure 2. Behavioral processes of individuals and groups in the space according to Aleksander Wallis

Source: Author's elaboration following A. Wallis (1983), Przestrzeń jako wartość, in: id. (1990), Socjologia przestrzeni, Niezależna Oficyna Wydawnicza, Warszawa, pp. 21-26.

The museums would not have come into existence had it not been for the Armenian-Azeri conflict over Nagorno-Karabakh dating back to the nineteenth century in modern times. By virtue of peace treaties which concluded the Russo-Persian wars in 1804-1813 and 1826-1828, Eastern Transcaucasia was incorporated into the Russian Empire. This territory was inhabited mainly by Azeris (whom tsarist officials erroneously called 'Caucasian Tatars' which was synonymous with Muslims) and it became 
a migration destination for different ethnic groups, including Armenians. This was stimulated by the rapidly developing oil extraction industry and new jobs associated with it. Historical considerations were also significant for Armenians. An ancient Artsakh province, part of Caucasian Albania, was the basis for modern land claims. Additionally, in the early Middle Ages, one of the most important sacred monuments for Armenians, the Amaras monastery, was founded in the south of Nagorno-Karabakh. The monastery was founded by St. Gregory the Illuminator, who in 301 baptized the King of Armenia, Tirydates III, the first ruler ever to adopt Christianity as a state religion. In the same place, St. Mesrob Mashtots, the author of the Armenian alphabet, established a school teaching language on the basis of his translation of the Bible from the fifth century onwards. Amaras is therefore a foundation of the Armenian national identity.

The nineteenth century witnessed the influx of several hundred thousand Armenians who were aware of their own separate identity (Kwiatkiewicz, 2013: 48), which triggered tensions with Azeris. They were frequently fueled and used by tsarist authorities. Mutual hostilities escalated during the 1905 revolution, killing thousands of Azeris and Armenians (exact estimates vary) as a result of clashes and pogroms (cf. Kwiatkiewicz, 2013: 48-49; Świętochowski, 2006: 45-49). The most violent of these were fought in Nagorno-Karabakh. In this conflict, religion was an indicator of being on this side or the other: Shia Islam in the case of Azeris and Christianity in the case of Armenians (Armenian Apostolic Church).

The following years brought political changes which were essential for the future of both ethnic groups. The Ottoman Empire collapsed in the wake of World War I. Before that, however, Turks committed a genocide of Armenians who, alongside Pontine Greeks and Assyrians, were considered an obstacle for the Young Turk nationalists in their implementation of Pan-Turkism, which aimed for the unification of all Turkic peoples. The Armenians, who were neither Muslim nor Turkic, were accused of collaborating with the enemy - the Russian Empire. The activities inspired and planned by the Turkish Minister of the Interior, Talaat Pasha, resulted in approximately 1.5 million people being killed in 1915-1917, accounting for ca. 75\% of the entire Armenian population in the Ottoman Empire.

As the genocide was drawing to an end, the monarchy in Russia was replaced by a republic after the February and October Revolutions, eventually bringing communists to power. Despite political changes, the policy of the Communist Party towards dependent states continued to follow the ancient Roman divide et impera rule, in the same way as the tsarist authorities. In the unstable political situation, the authorities of independent Armenia and Azerbaijan attempted to resolve the status of the disputed territory by force. The conflict was concluded in 1920 after intervention by the Red Army, and the future of the region was decided by the Soviet authorities. ${ }^{3}$ On July 4, 1923, Nagorno-Karabakh, which was inhabited mainly by Armenians, was incorporated into an autonomous Azerbaijan Socialist Soviet Republic. The name of the

${ }^{3}$ According to material from the permanent exhibition at the Artsakh State Museum of History and Country Studies in Stepanakert (as of November 2017), this was a decision of Vladimir Lenin; he made it in spite of a note by Georgy Chicherin regarding ethnic relations in Nagorno-Karabakh who indicated that the Armenians were in the majority there. 
territory was changed to Nagorno-Karabakh Autonomous Oblast (NKAO) in 1936. Przemysław Adamczewski notes that this was the only instance in Soviet policy in which an autonomous administrative unit was established for an ethnic group (Armenians) despite a titular republic having been established - the Armenian Socialist Soviet Republic (Adamczewski, 2012b: 164). Over the following fifty years, ethnic tensions did not intensify under the totalitarian regime for fear of repression, including forced resettlement. It was only in the period of Mikhail Gorbachev's perestroika and glasnost that the situation began to change. The Armenians took advantage of the situation, and in the late 1987 began persecuting Azeris living in the Armenian SSR, which led to the emergence of internally displaced persons in the USSR. On February 27, 1988, a pogrom targeted the Armenian population in Sumgait, Azerbaijan. Attempts to find a political solution to the conflict failed. Although the tensions escalated, in the face of the advancing collapse of the federation the Soviet authorities did not resort to an armed intervention to pacify the situation. Steps that were taken were only temporary.

On September 2, 1991, Armenian separatists announced the establishment of the Nagorno-Karabakh Republic (NKR) within the borders of the then Autonomous Oblast. The Supreme Council of the Azerbaijan SSR responded by liquidating the NKAO. The Armenians in Karabakh did not recognize this decision and announced that a referendum on the future of the contentious territory would be held in December 1991; separatists won this referendum. On January 6, 1992, independence was proclaimed and the Armenian army entered Nagorno-Karabakh in order to maintain the status quo. This violated the territorial integrity of Azerbaijan and was treated by its authorities as casus belli. Azerbaijan was supported by Muslim volunteers from other Caucasian states, including the Chechens commanded by Shamil Basayev. Initial clashes escalated into regular armed operations, which peaked in June 1992-September 1993. The campaign ended in Armenian military victory in February 1994, and their taking control of Nagorno-Karabakh. The seven Azerbaijani regions adjacent to Nagorno-Karabakh were occupied by the Armenian Army, forming the 'security zone.' The parties did not sign a peace treaty, and only a ceasefire agreement was secured (on May 5, 1994, the Bishkek Protocol was signed, having been negotiated by the representatives of the CIS), to be subsequently violated in a number of border incidents.

False information concerning the number of casualties was propagated and disseminated (Waal, 2004: 285). The credibility of these figures is justifiably questioned, especially regarding the number people killed on both sides. Data on the scale of displacement seems more credible, especially as regards internal displacement. Approximately 11,000 Azerbaijanis and 6,000 Armenians are estimated to have died as a result of armed operations in 1988-1994 (Świętochowski, 2006: 171-172), with further 5,000 and over 500 people respectively considered missing (Adamczewski, 2012a: 197-198). Additionally, approximately 530,000 Azerbaijanis were internally displaced in 1991-1994, while further 186,000 fled Armenia as refugees (Kurdish Muslims and Russians shared the same fate) (Adamczewski, 2012a: 198). According to calculations of Arif Yunusov, quoted by Thomas de Waal, 343,000 people on the Armenian side faced exile (unpublished article by Yunusov, after: Waal, 2004: 285). 
The conduct of Armenia and the Nagorno-Karabakh authorities constituted a tort under international law, which prohibits ius ad bellum. This was reflected in the 1993 resolutions of the UN Security Council, which stressed that it is inadmissible to use force in order to acquire territory, requested the parties to cease their military operations, and called Armenia to withdraw from the occupied Azerbaijani territories. ${ }^{4}$ The right to self-determination ensured in the Charter of the United Nations was not applicable in this case, as the territorial integrity of existing states cannot be violated. Armenia was partially isolated in the international arena. Azerbaijan was supported by Turkey. The position of the Russian authorities consisted of alternate (and sometimes also simultaneous) support for both sides. Ultimately, however, the Russians opted for the policy of the Armenian authorities.

The embargo imposed by Azerbaijan, and primarily by Turkey, inhibited the development of Armenia, which had an adverse impact on the NKR as well. The NKR, which used the Armenian currency, found itself in an economic meltdown and political isolation. In subsequent years, the NKR was recognized only by Abkhazia, South Ossetia and Transnistria; that is, by other self-proclaimed republics. Significantly, the NKR was not recognized by Armenia, which officially declared that it would refrain from any acts in this area until the peaceful settlement of relations with Azerbaijan. This also involved refraining from any integration measures towards Nagorno-Karabakh (Czachor, 2014: 350). On the other hand, the NKR's aspirations for independence were to be confirmed by the adoption of a constitution in 2006, by way of a referendum.

To commemorate the Karabakh Armenians who died or went missing as a result of the armed conflict with Azerbaijan, two museums were created in Stepanakert: the MMPS and the MMMW. The initiative came from families of victims gathered in the NKR Union of Perished Soldiers' Mothers and Relatives (for the MMPS) and the Union of Relatives of Missing Warriors of the NKR (for the MMMW). Both organizations dealt with the administration of the museums and the collection and archiving of documents and exhibits.

The choice of Stepanakert was not accidental. Originally, the city was called Khankendi (this name is still used by Azerbaijanis) and it was only after the massacre in Shusha in 1920 that it became the main administrative center of the region. In 1923, it was renamed Stepanakert to commemorate Stepan Shahumyan, a Bolshevik activist known as 'Lenin of the Caucasus,' shot by anti-communists in 1918. The city performed the functions of the capital during the NKAO period, and, after the proclamation of the NKR, it became the capital of the unrecognized republic - the seat of government. The museums were thus created in the largest, most populous and most important city of Nagorno-Karabakh.

Both museums are located in one monumental edifice with a front decorated with a colonnade and arcades, showing classic inspirations of its creators (Photo 1). Two separate entrances lead to them (Photos 2 and 6). They are several dozen meters away from each other. This distance does not mean much, however, which is why Znaniecki and Wallis did not pay much attention to measurable quantities. What was more im-

${ }^{4}$ The resolutions concerned include: S/RES/822 (April 3, 1993), S/RES/853 (July 29, 1993), S/RES/874 (October 14, 1993), S/RES/884 (November 12, 1993), https://undocs.org (accessed on October 11, 2018). 
portant was the place of the given institution in the panorama of the city, that is, its location vis-à-vis other objects - a relationship. Only the identification of these conditions encouraged research that went beyond the recognition of values considered to be objective.

The building that hosts the museums is located on 25 Vazgen Sargsyan, which is the main transportation artery of the capital of the NKR. The Presidential Palace is nearby, and the Parliament a little further. The central location of the museums does not mean, however, that this is the geodetic center of the agglomeration, but it is defined by the prism of social functions fulfilled by the defined space (Ziółkowski, 1990: 246). According to Wallis, this is a "cultural territory" which is an "object of intense and long-lasting interactions between the set of material, esthetic and symbolic values concentrated there, and a specific group" (Wallis, 1979: 17).

The monumental character of the building, together with its aesthetic values and the proximity of government buildings, signifies the importance of the institution. There are, however, 'cracks' in the discourse constructed. The museums are located at the back of the building (Photo 2), in several rooms adapted for the purpose of the exhibition. They occupy a small part of the cubature of the whole building. The door which leads to them (Photo 6) is in stark contrast with the scale of the front door (Photo 1).

According to the notice on the entrance doors, the museums are open six days a week; from Monday to Saturday, 9 a.m.-6 p.m. However, visiting is only possible when the few members of staff are present. Staff members combine different posts and functions found in traditional museums, such as custodian, curator, guide, educator, security guard, etc. On account of the character of their tasks, it seems more appropriate to talk about them as 'exhibition wardens.' In both museums, this role was carried out by older women.

Exploring a given space means individually experiencing a new place, which is necessary to organize activities and make decisions. In the case of both museums in Stepanakert, the fundamental experience is the feeling of a 'homelike' atmosphere. The floors are covered with rugs and plants sit on the windowsills. The intimacy of the rooms, the variety and multitude of objects presented and their amateurish character, exemplified by a mannequin wearing a uniform and a felt pen-drawn beard, and certain solutions, such as a PVC window serving as a display cabinet, distinguish the MMPS and MMMW from the majority of commemorative museums, which are accused of estheticizing tragedy by their sterility.

A characteristic feature shared by both institutions is the identical manner of displaying primarily black-and-white photos of killed and missing people, which hang in rows from the ceiling to the floor in almost all rooms (Photos 3 and 4). This arrangement of the space is reminiscent of ancient Roman columbaria and - in the MMPS - also plays a similar role, commemorating a large number of dead people. Vases with (mainly artificial) flowers, arranged in the same way as in cemeteries, are another funereal feature. In the MMMW, the pictures of missing people and the archive of the museum serve the purpose of commemorating and documenting the profiles and personal details of people who could possibly still be being held in Azerbaijani prisons. 
Other pictures present scenes from the time of the armed conflict, military parades and other events, and people of importance for the inhabitants of the NKR. A separate cabinet in the MMPS is dedicated to photographs and memorabilia related to female victims of the conflict.

Items presented in the exhibition are donations, dominated by personal items such as personal hygiene items, writing utensils and the Bible. Many of the items presented are hand-made curios made because of shortage of supplies, such as long and short weapons, grenades and knives, and entertainment objects such as playing cards and chess, which is a national sport for Armenians. The exhibits include examples of soldiers' handicrafts, busts, battle plans and scale models. The MMPS also features wedding clothes: a dress, a suit and footwear bought for an upcoming ceremony which never took place because the conflict broke out. There are also wedding musical instruments which never served their purpose.

There is no permanent exhibition in the sense of a copyright-protected closed set in the MMPS or in the MMMW. This is demonstrated by the practice of updating the exhibitions, as evidenced by a section of the MMPS exhibition dedicated to the 2016 'April War.'

\section{ASSIGNING VALUE TO THE MUSEUM SPACE}

The MMPS and MMMW constitute a part of the social space for Armenians in Nagorno-Karabakh. Thus, they both possess and form values which affect both their holders and people outside of this group. Wallis recommended analyzing them on a microscale, namely in relation to individuals, and distinguishing instrumental, situational and existential values of the space. They constitute general categories which need to be characterized in further detail. Instrumental values include functionality defined by name (e.g. street or cemetery), character (sacral or secular, private or public, open or closed) and orientation easiness (visibility and legibility of signs). Situational values consist of a sense of security (potential conflict or threat), identification (what is meant here is one's identification with the place and the potential to establish friendly relations with other people in a specific space), anonymity (or - in other terms - identifiability), the freedom to choose a defined social role (e.g. researcher or tourist) and - last but not least - prestige and self-fulfillment (unlike Wallis, we mean here a subjective criterion of stratification which consists of choosing inaccessible vacation destinations). Existential values, in turn, ensure emotional, esthetic and intellectual experiences related to one's sense of identity and worldview (Wallis, 1983: 28-30) (Figure 3).

Applying Wallis' criteria to the MMPS and MMMW and calling both these institutions 'museums of remembrance,' their functional character is recognized and a defined instrumental value is attributed. The concern here is not the formal name of 'museum of remembrance' but the actual task performed, namely the commemoration of the Armenians who were killed or went missing during the armed conflict with Azerbaijan. This task makes both museums "cultural territories" thus confirming that the function implied by this name is actually performed (Wallis, 1979: 101). 
Figure 3. Values of the space and their features for individuals, according to Aleksander Wallis

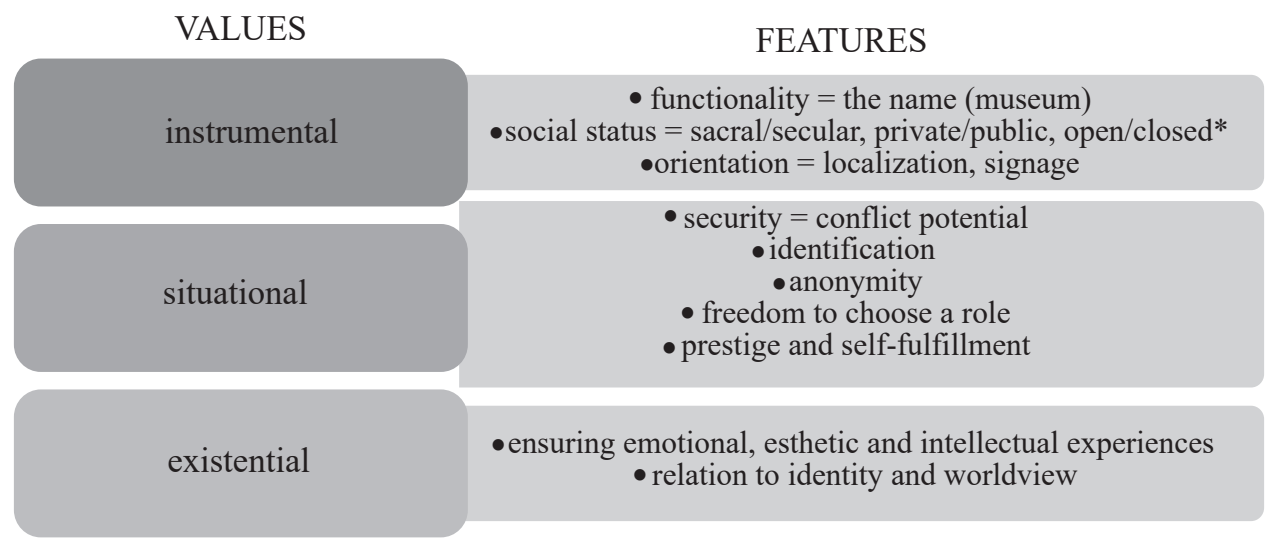

* For Wallis: private/institutional, public/closed.

Source: Author's elaboration following: A. Wallis (1983), Przestrzeń jako wartość, in: id. (1990), Socjologia przestrzeni, Niezależna Oficyna Wydawnicza, Warszawa, pp. 28-31.

The character of both museums is not as unambiguous as their name, though. For a member of a group which founded them, and for whom the museums operate, they are sacral places featuring numerous religious symbols (primarily crosses). They were founded as chambers of remembrance for the victims, which is evidenced by the manner in which the photos of killed and missing people are displayed and the floral decorations, which are reminiscent of funeral practice. Displaying personal belongings of victims and their families in the cases transforms them into relics. For non-Armenians, these museums are secular public institutions and the items collected are museum exhibits.

The museums offer free entry. Volunteers can offer donations for veteran organizations. Although there are no formal obstacles, reaching the museums may be troublesome for people from outside of Stepanakert. This is because the entry is located on the street of Garegin Nzhdeh (Photo 2), which requires visitors to walk around the entire building. There are no information boards in languages other than Armenian, which makes it difficult to find the way in. There is no set route around the museums, but it is determined by the arrangement of the space. The majority of descriptions are in Armenian. People who do not speak Armenian are helped out by the exhibition wardens, who also act as Russian-speaking guides. Personal involvement of the wardens is their distinguishing feature, which follows from the fact that they tell stories of their deceased or missing relatives. Every item in a display case is associated with a separate story told by its donator. Tourist traffic is not heavy, so the wardens do not have to give their attention to several people at the same time. Therefore, a visit to the museum is ennobling for every visitor, as they receive the full attention of the museum staff, which takes the form of questions about their country of origin and their reasons for visiting the region, but primarily translates into time dedicated by the museum staff to sharing their memories of the events which resulted in the institutions being established.

Regarding situational values, local visitors are not anonymous in the museums, because the population of the city is not very large and it is customary to take children 
and young students to the museums. The situation of tourists who usually travel to Nagorno-Karabakh individually or in small groups is different. Although their identities are not verified at the entrance to the museums, they are asked about their country of origin and encouraged to leave an entry in the commemorative book, which they typically sign with their names. I experienced this myself when requested to make such an entry, which was a condition for the book to be completed in the MMPS. I did not say no.

If a person identifies with a given community, they also identify with the space which belongs to this community. In the case of non-Armenians, their 'admission' to the sacred space reserved for Armenians (neither public nor private) is a reward for their presence in a place which is not recognized by international community. In order to reach Stepanakert, one is required to illegally cross the border between Armenia and the NKR. This is a crime punishable in Azerbaijan with imprisonment. Therefore, mere presence in the museums is treated as an expression of one's identification with one party to the Karabakh conflict - the Armenians. This makes the MMSP and MMMW a space of a potential conflict related to the roles assumed by people present in the museums. Since spatial values are treated as the common good of "individual groups and communities, this results in specific consequences for the spatial behavior of their members, as well as of individuals from the outside" (Wallis, 1975: 15).

Behavior is governed by specific rules rooted in customs and social norms, according to which it is inadmissible to question the purposefulness of the deaths of victims portrayed in the photos. The children who visited the MMPS attentively listened to tales of the heroism of the victims and then enquired about the people on the photos.

One way to oppose a community is to violate the rules it follows. Such an act which the holder of the space deems a threat to themselves may involve sanctions or repressions against the perpetrator (Wallis, 1983, p. 32). The same rule applies to Armenians and non-Armenians alike. Whether the rules are observed is somewhat verified in the MMPS by the visitors' response to the invitation to wipe their shoes on the flag of Azerbaijan spread on the floor in front of a scale model marked "Shusha" (Photo 5). Shusha is a symbolic city in Nagorno-Karabakh. It is called the 'gate to Karabakh' ('who rules Shusha rules Nagorno-Karabakh'). This is a consequence of the city's location on a hill, the control over which is essential strategically. Ethnic relations were transformed in Shusha in the twentieth century. In 1920, approximately 2,000 Armenians were murdered in Shusha. After this massacre, the city fell into decline and lost its status as the main cultural and political center in the region. In Soviet times, it regained its significance as a mountain resort. During this period, Azerbaijanis located their military base here, which was the closest to Armenia. This made Shusha a convenient location to shell Armenian-controlled Stepanakert which lies below. On May 9, 1992, following a successful Armenian offensive, the city was conquered and the day of the 'liberation of Shusha' was celebrated as a national holiday in the NKR. This was the first Armenian military victory in the conflict with Azerbaijan. To commemorate it, Armenians displayed a restored T-72 tank which had been destroyed on the day preceding this victory by the road from Stepanakert to Shusha.

My refusal to desecrate the flag of Azerbaijan did not spark any negative response among the staff. However, I signed the commemorative books and made a donation 
to veteran organizations. The option to oppose the practice adopted in the museum evidenced my freedom to choose a role. This immunity seemed to be closely associated with my 'guest' status of a person who does not belong to the group but who was admitted to the space owned by this group. Znaniecki analyzed this in the examples of an envoy and missionary, among others. Nowadays, the equivalent of this type of practice is the situation of a tourist/traveler, to whom the principles of hospitality apply in Nagorno-Karabakh. At the same time, there is no room for the 'guest-researcher' Znaniecki wrote about, because one's presence "within the framework of a given collective spatial value is socially experienced as a kind of participation in this value" (Znaniecki, 1938: 107, 94). Critical reflection regarding the purposefulness of the armed operations and the scale of sacrifices is therefore not permitted. Visitors from the outside are desired or tolerated as long as they adhere to the desired guest model. The problem is when a 'stray' arrives - a person whose presence may potentially trigger conflicts because they do not observe the rules. A 'stray' may be exemplified by a tourist who refuses to desecrate the flag of Azerbaijan and criticizes this practice.

The freedom to choose roles applies also to people who administer the museums and act as exhibition wardens. Vera Grigoryan, ${ }^{5}$ who guided me around the MMMW, is an example here. She is the mother of one of the missing people, and gave a heartbreaking account of her personal tragedy. Her son was conscripted three months after his wedding, captured and - according to a film shot by the Red Cross - imprisoned in Azerbaijan. The woman helps to collect documents, archives materials gathered and organizes meetings with other mothers of missing fighters.

For non-Armenians, the visit to the museums in Stepanakert may serve the purpose of prestige and self-fulfillment. Mass tourism results in some travelers seeking less accessible locations, which are thus more desirable as vacation destinations. An account from Nagorno-Karabakh evidences one's visit to a place which is inaccessible for mass tourism. A visit to an unrecognized state involves little to no protection offered by insurance companies. On top of that, in the event of a possible future trip to Azerbaijan, care should be taken not to have the visa of the NKR stamped into one's passport; the visa form should be bought and kept until returning to the territory of Armenia. Such difficulties are an additional 'attraction' for adventurous tourists, and overcoming them may be a reason for satisfaction. Choosing Nagorno-Karabakh and visiting both museums may also be seen as an example of 'Grief Tourism' (Thanatourism) involving visits to the areas of armed conflicts or natural disasters (caused by natural forces or technical failure) as a result of which many people died and/or suffered.

The last group are existential values, which are difficult to separate as they are mutually related. In the case of the museums of remembrance in Stepanakert, a process takes place which Wallis described as serving the purpose of "accumulating selected material and symbolic values. [...] This allows us to treat these territories as both the products of groups and communities, and as a cultural environment which continuously exerts influence on those groups and communities. On the one hand, the territories are the expression of the tastes, preferences, needs, lifestyles and abilities of their users

${ }^{5}$ I decided to use authentic personal details due to the publications of the image and statements available on the Internet by Vera Grigoryan for the Humanitarian Aid Relief Trust (HART), posted to the HART website on February 26, 2012 (see the references). 
and, on the other, they continuously form these groups and communities consolidating a specific set of values in them. This is one of the most momentous feedbacks in culture" (Wallis, 1979: 104). Thus the MMPS and MMMW are not neutral. The same applies to all cultural institutions characterized by playing a fundamental role in forming national values, constructing and reproducing historical, political and social relations (Johnson-Cunningham, 2018: 2). A museum is discourse (or a representation), it is 'text' made up of signs which may be subject to control (Hetherington, 2000: 447). For non-Armenians, both museums mainly serve the purpose of providing intellectual experiences related to the exploration of the place and its history. For Armenians, however, they fulfill emotional needs related to a sense of identity. Identity and place are mutually related elements which tie one thing with another (Malpas, 1999: 177).

The figure of Other is significant here; of an Azerbaijani, a Muslim and an enemy, who is absent from both exhibitions but who is accused of being the perpetrator of the tragedy. The presence of the children from local schools visiting the MMPS is a lesson in patriotism; and the people in the photos are the heroes who made the greatest sacrifice for the noblest cause - Nagorno-Karabakh being Armenian in terms of sovereignty (self-governance and total powers) and the exclusive right to the territory it occupies.

When interpreted in terms of Freud's psychoanalytical paradigm, composing the exhibition, administering it and one's presence in the museums are part of the 'work of mourning' and - as such - are also the implementation of existential spatial values related to emotions. "Mourning is regularly the reaction to the loss of a loved person, or to the loss of some abstraction which has taken the place of one, such as one's country, liberty, an ideal, and so on. In some people, the same influences produce melancholia instead of mourning and we consequently suspect them of a pathological disposition" (Freud, 1957: 237). Although the state of mourning deviates from the state of normality, it is assumed to be overcome at some point and it is pointless, or actually harmful, to break it. Mourning as such is not an object of therapy. Melancholia, in turn is distinguished by "a profoundly painful dejection, cessation of interest in the outside world, loss of the capacity to love, inhibition of all activity, and a lowering of the selfregarding feelings to a degree that finds utterance in self-reproaches and self-revilings, and culminates in a delusional expectation of punishment" (ibid.). In both cases, the person who has suffered a loss feels pain and rejects any activity which is not related to the commemoration of the deceased person. Both mourning and melancholia pass. Mourning is typically caused by the actual death of the loved one, while melancholia may be a response to all kinds of resentments and disappointments. The 'work of mourning' is about adjusting to the reality from which the object of the affection is absent, and results in liberation. The situation is different with melancholia. It is manifested by disparagement of oneself, rather than of the world around. This is a disease related to a sense of guilt, a disease in which "the superego reveals itself as a pure culture of the death instinct, to the point of suicide" (Ricśur, 1970: 301).

The loss of close relatives has turned survivors into victims. The study by the Union of Relatives of the Artsakh War Missing in Action Soldiers (URAWMS), published in 2013 to celebrate the fifteenth anniversary of the union, states the following: "The women, who have grown their children alone, are untimely touched with grey, the children are growing up, strongly missing their fathers, and now also their grandfathers" 
(URAWMS, 2013: $35^{6}$ ). For the families of killed and missing people, both museums are a form of therapy. The attempts to overcome the loss of relatives are especially clear in women who have become involved in creating and administering the museums and running the archives. They are mostly mothers of killed or missing fighters. They either were, or - if their health allows that - still are the curators of remembrance for victims, and their role is to give testimony. An example is the interview given by the late Galy Arustamyan - an MMPS icon - about her son, Kirkor, who "was 17 when he joined the liberation movement," and was killed four years later, in 1992. On the tenth anniversary of his death, in 2002, Galy Arustamyan and the NKR Union of Perished Soldiers' Mothers and Relatives, opened the exhibition paying "tribute to those who lost their lives fighting for Karabakh's self-determination" to the public (Barsoumian, 2013). The exhibition features 3,350 portraits of killed people, which were reportedly obtained from their families and taken to Yerevan, enlarged, developed and uniformly framed to be hung in the MMPS. In 1998, Galy Arustamyan also published an 895page collection of profiles and photographs of Armenian fighters who were killed or went missing in 1988-2009. The MMPS is therefore a form of 'work of mourning.' Unlike in Freud's study, however, this work is about continuously working through (rather than getting over) grief for the lost object of love. This is incessant work manifested by physical presence in the space of the museum.

Since the museums are also public institutions, the presence of mothers of killed and missing people means their leaving their private realm, associated with the home, which is enforced by the circumstances. Working for the museums substitutes their lost family life and is a way of dealing with the model of female self-fulfillment formed by their culture. Women, as mothers of victims, are a model of making a specific sacrifice for their fatherland, thereby becoming sanctified. Their suffering after the experience of losing a child makes them reminiscent of Mary - the mother of Christ. This is expressed by the representations of Holy Mary and a woman with the body of an adult son, featured in both museums.

The mutual permeation of religious and martyrdom aspects mythologizes the mothers of fallen and missing fighters, synthesizing their idealization and tragedy. The tragedy of the former, however, differs from the situation of the latter, who do not know whether their sons have died or not and thus cannot mourn them. This is evident when Vera Grigoryan from the MMMW says that: "I pray that no mother sleeps with an open door" (waiting for her child to return) and: "Waiting is the most horrible suffering" (Grigoryan, 2012). The MMMW, established in 2004, on the tenth anniversary of the suspension of military operations, is therefore different than the MMPS. Its purpose is not to enable 'work of mourning,' as Freud would say, but rather provide a space for the melancholia which accompanies the families of missing people.

$$
* * *
$$

Nagorno-Karabakh is currently considered the most militarized area in the South Caucasus region. The key political decision-makers of Armenia come from Stepanakert.

${ }^{6}$ I obtained access to this publication thanks to Susanna Petrosyan, to whom I would like to extend my thanks for her help. 
The issue of the future of this territory is an important element of any electoral campaign in Armenia. Any plans to make concessions to the Azerbaijani side are opposed by Armenian nationalist and veteran circles. The memory of the armed conflict with Azerbaijan remains vivid and is reflected in numerous commemorative initiatives in the NKR, as exemplified by the Memorial Museum of the Perished Soldiers and the Memorial Museum - The Union of Relatives of Missing Warriors of the NKR in Stepanakert. These institutions are a synthesis of museum and funeral practices. To quote Aleksander Wallis, replacing 'monuments' with 'museums,' it may be concluded that they "were created to historicize current events" which "evoke the greatest emotions, tensions and conflicts" and stem from "profound moral needs." However, unlike monuments whose "artistic shape and symbolic meaning [...] permit different interpretations in formal and artistic categories as well as in the categories of meaning, ideology and politics" (Wallis, 1968), the two museums do not give such freedom. Besides commemoration, they also serve the purpose of constructing and consolidating hostility towards Azerbaijan - the raison d'être of the conflict over Nagorno-Karabakh. The conflict is the foundation of the idea of Artsakh and the main political implication of the spatial values represented by the MMPS and MMMW.

The unique character of these museums, however, is not related to the politicization of remembrance, which is a common feature of such establishments, but rather to the short temporal distance between the armed conflict and the emergence of the exhibitions. Consequently, the memory of the museums' creators has not been 'borrowed' and the message of the museums reflects the current attitude to Azerbaijan.

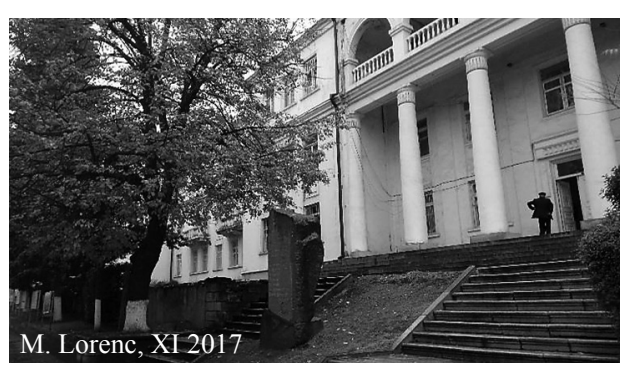

Photo 1. Front of the building at 25 Vazgen Sargsyan

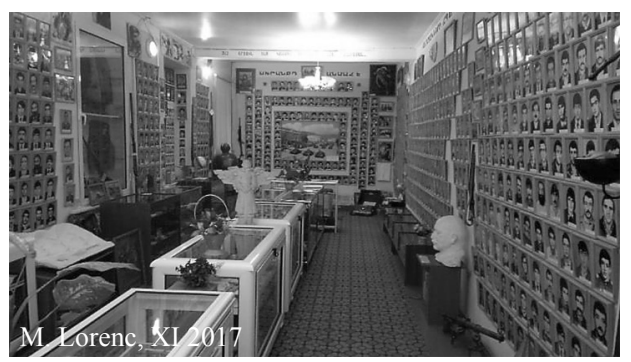

Photo 3. The NKR Memorial Museum of the Perished Soldiers

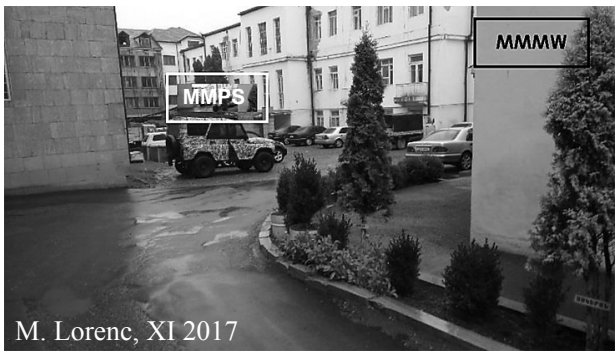

Photo 2. Back of the building with entrances to both museums marked, taken from the side of Garegin Nzhdeh

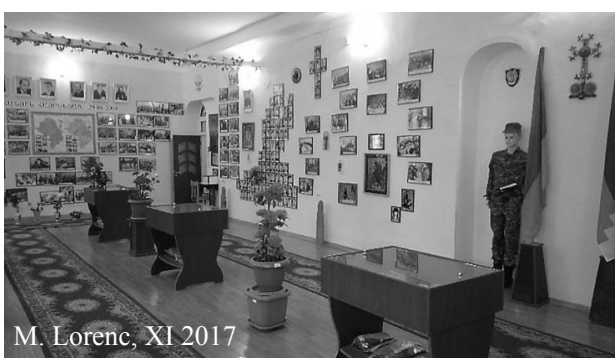

Photo 4. Memorial Museum. The Union of Relatives of Missing Warriors of the NKR 


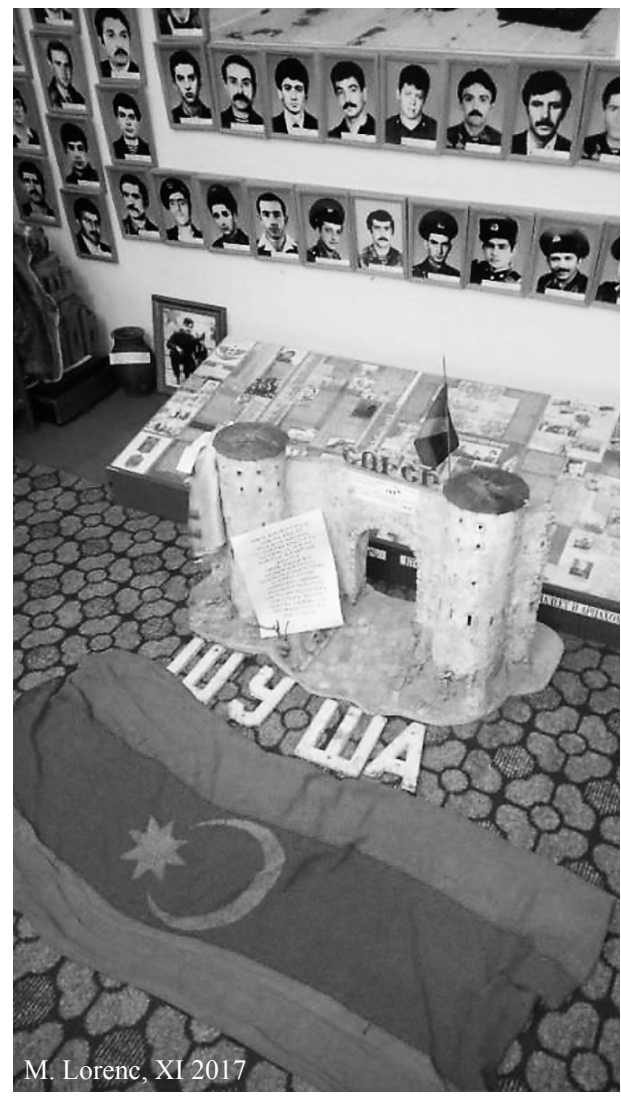

Photo 5. The NKR Memorial Museum of the Perished Soldiers

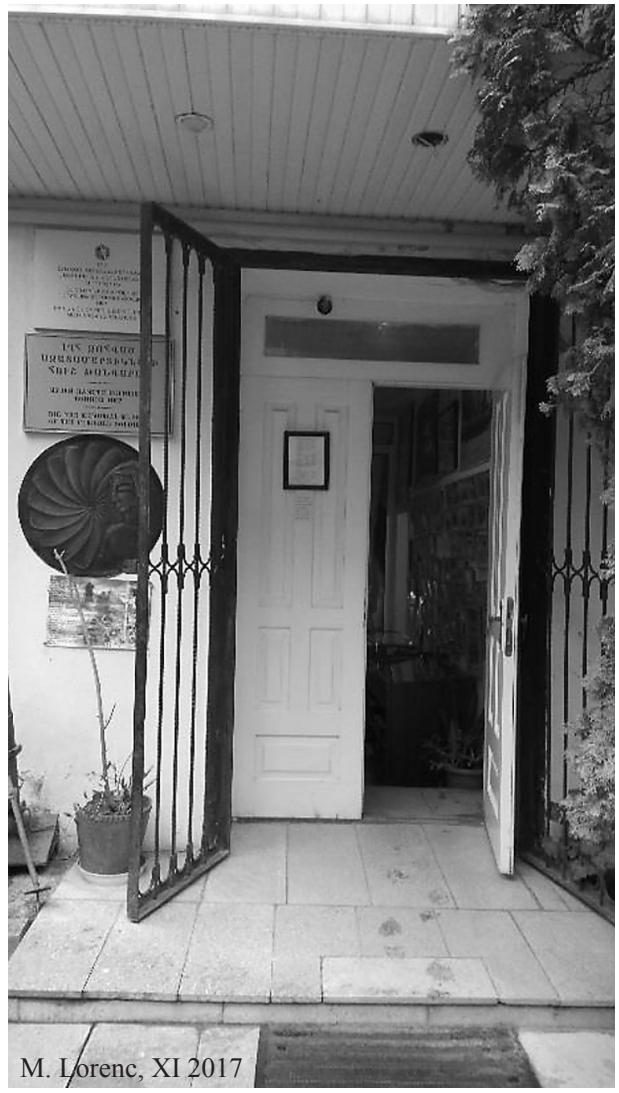

Photo 6. The NKR Memorial Museum of the Perished Soldiers

\section{REFERENCES}

Adamczewski P. (2012a), Górski Karabach w polityce niepodległego Azerbejdżanu, Wrocław.

Adamczewski P. (2012b), Przywództwo polityczne na poradzieckim obszarze o nieustalonym statusie. Casus Górskiego Karabachu, in: Kaukaz: mechanizmy legitymizacji i funkcjonowania elit politycznych, (ed.) T. Bodio, Vol. 7, Warszawa.

Barsoumian N. (2013), In the Name of Her Son: The Story Behind Artsakh's Museum of Fallen Soldiers, "Armenian Weekly" of August 31, https://armenianweekly.com/2013/08/31/in-thename-of-her-son-the-story-behind-artsakhs-museum-of-fallen-soldiers/ (January 10, 2019).

Czachor R. (2014), Abchazja, Osetia Poludniowa, Górski Karabach: geneza i funkcjonowanie systemów politycznych, Wrocław.

Denzin N. K. (1997), Interpretive Ethnography: Ethnographic Practices for the 21st Century, Thousand Oaks.

Flick U. (2004), Constructivism, in: A Companion to Qualitative Research, (eds.) U. Flick, E. von Kardorff, I. Steinke, London.

Foster H. (1988), Preface, in: Vision and Visuality, (ed.) H. Foster, Seattle. 
Freud S. (1957), Mourning and Melancholia, in: The Standard Edition of the Complete Psychological Works of Sigmund Freud, Vol. 14 (1914-1916). On the History of the Psycho-Analytic Movement. Papers on Metapsychology and Other Works, London.

Grigoryan V. (2012), Interview for Humanitarian Aid Relief Trust (HART), published on February 26, https://thekarabakhconversation.wordpress.com/page/3/ (September 10, 2018).

Hall S. (1997), Introduction, in: Representation: Cultural Representations and Signifying Practices, (ed.) S. Hall, London.

Hetherington K. (2000), Museums and the Visually Impaired: the Spatial Politics of Access, "The Sociological Review", Vol. 48 (3).

Holman-Jones S. (2009), Autoetnografia. Polityka tego, co osobiste, in: Metody badań jakościowych, (eds.) N. K. Denzin, Y. S. Lincoln, Warszawa.

Johnson-Cunningham S. (2018), Beyond Gallery Walls and Performance Halls: Five Essential Steps Museums and Other Cultural Institutions Must Take to Center People Communities, and Cultivate Effective Societal Change, "Museums \& Social Issues. A Journal of Reflective Discourse", Vol. 13, No. 1.

Kwiatkiewicz P. (2009), Azerbejdżan: ukształtowanie niepodległego państwa, Toruń.

Latour B. (2010), Splatajac na nowo to, co spoleczne, Kraków.

Malpas J. E. (1999), Place and Experience: A Philosophical Topography, Cambridge.

Pospiszyl K. (1991), Zygmunt Freud, Wrocław-Warszawa-Kraków.

Ricœur P. (1970), Freud and Philosophy: An Essay on Interpretation, New Haven-London.

Rose G. (2010), Interpretacja materiałów wizualnych. Krytyczna metodologia badań nad wizualnościq, Warszawa.

Sekula A. (1986), Reading an Archive: Photography between Labour and Capital, in: Photography/ Politics: 2, (eds.) P. Holland, J. Spence, S. Watney, London.

Spry T. (2001), Performing Autoethnography: An Embodied Methodological Praxis, "Qualitative Inquiry", No. 7.

Świętochowski T. (2006), Azerbejdżan, Warszawa.

The Union of Relatives of the Artsakh War Missing in Action Soldiers (URAWMS) (2013).

Wall T. de (2003), Black Garden: Armenia and Azerbaijan through Peace and War, New YorkLondon.

Wallis A. (1979), Informacja i gwar, Warszawa.

Wallis A. (1968), Miejsce pomnika w przestrzeni społecznej, Warszawa.

Wallis A. (1979), Obszar kulturowy, in: id. (1990), Socjologia przestrzeni, Warszawa.

Wallis A. (1983), Przestrzeń jako wartość, in: id. (1990), Socjologia przestrzeni, Warszawa.

Wallis A. (1990), Socjologia przestrzeni, (err.) E. Grabska-Wallis, M. Ofierska, Warszawa.

Wallis A. (1967), Socjologia wielkiego miasta, Warszawa.

Wallis A. (1975), Znanieckiego „, Socjologiczne podstawy ekologii ludzkiej”, idem (1990), Socjologia przestrzeni, Warszawa.

Yunusov A. (1999), Armyano-Azerbaidzhansky Konflikt: Migratsionnye Aspekty [The ArmenianAzerbaijani conflict: Aspects of migration], in: Migratsionnaya Situatsiya v Stranakh SNG [The migration situation in CIS countries], (ed.) Zh. Zaionchovskaya, Moscow [unpublished] Unmarked.

Ziółkowski J. (1990), Posłowie, in: Wallis A. (1990), Socjologia przestrzeni, Warszawa.

Znaniecki F. (1938), Socjologiczne podstawy ekologii ludzkiej, "Ruch Prawniczy, Ekonomiczny i Socjologiczny", No. 1. 


\begin{abstract}
Nagorno-Karabakh is currently considered the most militarized area in the South Caucasus region. The key political decision-makers of Armenia come from Stepanakert. The issue of the future of this territory is an important element of any electoral campaign in Armenia. Any plans to make concessions to the Azerbaijani side are opposed by Armenian nationalist and veteran circles. The memory of the armed conflict with Azerbaijan remains vivid and is reflected in numerous commemorative initiatives in the NKR, as exemplified by the Memorial Museum of the Perished Soldiers and the Memorial Museum - The Union of Relatives of Missing Warriors of the NKR in Stepanakert. These institutions are a synthesis of museum and funeral practices. To quote Aleksander Wallis, replacing 'monuments' with 'museums,' it may be concluded that they "were created to historicize current events" which "evoke the greatest emotions, tensions and conflicts" and stem from "profound moral needs." However, unlike monuments whose "artistic shape and symbolic meaning [...] permit different interpretations in formal and artistic categories as well as in the categories of meaning, ideology and politics" (Wallis, 1968), the two museums do not give such freedom. Besides commemoration, they also serve the purpose of constructing and consolidating hostility towards Azerbaijan - the raison d'être of the conflict over Nagorno-Karabakh. The conflict is the foundation of the idea of Artsakh and the main political implication of the spatial values represented by the MMPS and MMMW.

The unique character of these museums, however, is not related to the politicization of remembrance, which is a common feature of such establishments, but rather to the short temporal distance between the armed conflict and the emergence of the exhibitions. Consequently, the memory of the museums' creators has not been 'borrowed' and the message of the museums reflects the current attitude to Azerbaijan.
\end{abstract}

Keywords: the NKR Memorial Museum of the Perished Soldiers, the Memorial Museum of Missing Warriors of the NKR, the 'museums of the frontline', Stepanakert, the conflict over Nagorno-Karabakh

\title{
MUZEA FRONTOWE STEPANAKERTU, CZYLI O ORMIAŃSKIEJ PAMIĘCI KONFLIKTU ZBROJNEGO Z AZERBEJDŻANEM
}

\section{STRESZCZENIE}

Celem tekstu jest próba aplikacji kategorii „wartości przestrzennych”, w rozumieniu Floriana Znanieckiego i Aleksandra Wallisa, na grunt badań poświęconych praktykom komemoracyjnym na przykładzie Muzeum Poległych Żołnierzy i Muzeum Zaginionych Wojowników, zlokalizowanych w Stepanakercie - stolicy Republiki Górskiego Karabachu.

Pytanie podstawowe sprowadza się do tego, jakie są wartości przestrzenne obu muzeów? Zgodnie z przyjętą hipotezą, obie instytucje stanowią syntezę praktyk muzealnych i funeralnych. Poza funkcją komemoracją, polegającą na upamiętnieniu ormiańskich ofiar konfliktu zbrojnego o Górski Karabach, służą one konstruowaniu i utrwalaniu wrogości wobec Azerbejdżanów. Ma ona charakter fundacyjny dla idei Arcach i stanowi główną implikację polityczną wartości przestrzennych reprezentowanych przez te placówki, uzasadniając nazywanie ich „muzeami frontowymi”.

Do opracowania materiałów pozyskanych w wyniku badań terenowych użyto metod jakościowych, w tym głównie analizy dyskursu, która pozwoliła potraktować muzea i ich otoczenie 
jako archiwa, które nie są neutralne, gdyż wiążą się z władzą gromadzenia oraz władzą samych instytucji. Pomocniczo zaś użyto autoetnografii i performansu.

Słowa kluczowe: Muzeum Pamięci Poległych Żołnierzy, Muzeum Pamięci Zaginionych Bojowników, „muzea frontowe”, Stepanakert, konflikt o Górski Karabach 
